\title{
Geomechanical modeling as a basic step in secondary reservoir stimulation treatment design
}

\begin{abstract}
Unconventional reservoirs require a new approach at every level of the operation on the object, starting from exploration of reservoir formation, through well and drilling design and ending with well completion including reservoir development. Due to the specific nature of unconventional reservoir properties, the hydrocarbons bearing formation requires stimulation treatments like hydraulic fracturing, aiming to improve the pores connectivity and enabling the free flow of the gas into the well bore, which in the end brings production rates to economic levels. In the paper a geomechanical model of the synthetic object, allowing the analysis of many processes accompanying real hydrocarbons exploitation was presented. Special attention was paid to the demonstration of changes in the state of stress in the geological formation, due to the exploitation of hydrocarbons and the influence of the initial horizontal stresses relationship $\left(\sigma_{H} / \sigma_{h}\right)$, on the effectiveness of stimulation treatments in unconventional formations.
\end{abstract}

Key words: unconventional reservoirs, hydraulic fracturing, principal stresses, elastic properties, strength properties.

\section{Modelowanie geomechaniczne jako element optymalizacji wtórnego szczelinowania}

Formacje złożowe o charakterze niekonwencjonalnym do poprawy właściwości transportowych i uzyskania eksploatacji na poziomie uzasadnionym ekonomicznie wymagają stymulacji poprzez szczelinowanie hydrauliczne, którego efektywność uzależniona jest od panujących warunków mechanicznych, m.in. właściwości sprężystych szczelinowanego ośrodka i oddziałującego pola naprężeń. W pracy przedstawiono i omówiono wyniki modelowania geomechanicznego obiektu syntetycznego, pozwalającego na analizę wielu procesów towarzyszących wydobyciu węglowodorów. Specjalną uwagę poświęcono zmianom w rozkładzie naprężeń w górotworze będących skutkiem eksploatacji oraz wpływowi początkowego układu naprężeń poziomych na efektywność zabiegów udostępnienia niekonwencjonalnej formacji złożowej.

Słowa kluczowe: złoża niekonwencjonalne, szczelinowanie hydrauliczne, pole naprężeń, właściwości sprężyste.

\section{Introduction}

Significant differences in parameters characterizing the shale formation, being the source and reservoir rock at the same time, depending on the deposition environment and geological structure, create an important challenge for the quantitative assessment of phenomena and effects, related to development and exploitation of reservoir objects described above. With the above in mind, the literal transfer of knowledge and experience between reservoir objects within different geological provinces seems to be unacceptable [21].

American experience in the exploitation of natural gas and crude oil from the geological formations revealing reservoir parameters of low quality, inspired oil companies to extend the exploration of such unconventional objects on other continents. At the moment, intensive works associated with the characterization of unconventional reservoirs is ongoing in some countries around the world. One of recent EIA (Energy Information Administration) reports indicate, that Europe itself has reserves with a total volume of 70 trillion cubic meters of natural gas in shale formations, half of which would come from shale sedimentary basins located in France and Poland.

The unconventional accumulations, that the authors are referring to, are characterized by large resource volumes, that cannot be extracted economically with the use of conventional methods [6]. What is more, they reveal poor quality reservoir properties with the absolute gas permeability $<0.5 \mathrm{mD}$ $\left(1 \mathrm{mD}=9.869233 \cdot 10^{-10} \mathrm{~m}^{2}\right)$ and porosity less than $10 \%$. In contrast to the conventional objects, unconventional reservoir requires a new approach at every level of the operation on 
the object, starting from exploration of reservoir formation [20], through well and drilling design, and ending with well completion, including reservoir development. The latter includes hydraulic fracturing, which is a technological treatment aimed at the generation of an artificial network of fractures, allowing for gas flow from the geological formation [14]. At each stage of these operations, it is essential to recognize the mechanical properties of the hydrocarbons bearing formation, within the so called Mechanical Earth Model. The knowledge about the distribution of geomechanical parameters, among others, allows for horizontal well section design, reservoir development design, and also elimination of drilling problems which directly translates into drilling time and costs reduction.

The need for characterization of the geological object, particularly in view of future operations upon the reservoir, is already a well-known matter, what's more it demands, that all analyses are performed in '3D optical lens'.

It is also known, that the Mechanical Earth Model, according to the definition [11] is the numerical representation of "the mechanical state of geological medium", achieved by integrating mutual relations between distribution of the pressure in the rock medium and the pore pressure.

The integration platform of these parameters, as well as geological, geophysical, laboratory analyses results, well logs and reservoir engineering data, is 3D seismic.
To emphasize the importance of the consistent integration of parameters describing geological medium, the relationship binding the fundamental mechanical parameters characterizing the geological objects with the elastic properties, such as shear (transverse) seismic wave-S wave propagation velocity given by Sayers [18], is worth mentioning.

$$
V=a_{1}-a_{2} \cdot \phi-a_{3} \cdot C+a_{4} \cdot(S-P)^{a 5}
$$

where:

$V$ - stands for $P$-wave velocity $[\mathrm{ft} / \mathrm{s} ; \mathrm{m} / \mathrm{s}]$,

$P$ - pore pressure [psi; $\mathrm{MPa}$ ],

$S$ - overburden pressure [psi; $\mathrm{MPa}$ ],

$\phi$ - porosity [expressed as percentage or a decimal],

$C$ - clay content [expressed as percentage or a decimal] and the coefficients $a_{i}$, obtained from well calibration.

The subject of this paper is a geomechanical model of a synthetic object, which allows for the analysis of many processes accompanying the real exploitation of hydrocarbons. Special attention was paid to the presentation of changes in the state of stress in the geological formation, as a result of exploitation of hydrocarbons and the influence of the initial horizontal stresses relationship $\left(\sigma_{H} / \sigma_{h}\right)$, on the effectiveness of stimulation treatments in unconventional formation.

\section{Mechanical earth models}

Geomechanical model also known as Mechanical Earth Model (MEM) is by definition given by Herwanger and Koutsabeloulis [11], a numerical representation of the geomechanical state of the reservoir object, oil field or sedimentary basin.
Mechanical Earth Model integrates data and knowledge about the relationship between:

- distribution of the rock masses properties (elastic properties and rock strength),

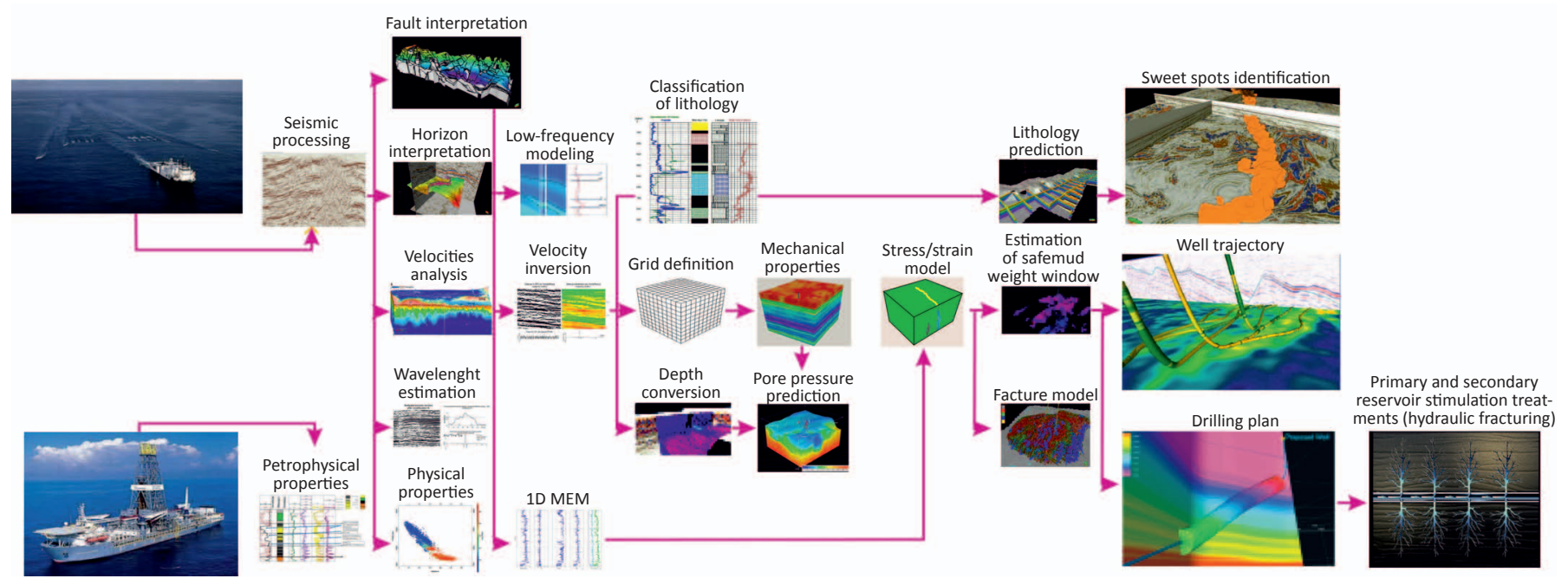

Fig. 1. Simplified diagram illustrating Mechanical Earth Model workflow. The Mechanical Earth Model involves a great variety of data such as seismic, well log data and laboratory analysis results. These data are essential for the modeling, which results in the identification of perspective areas called sweet spots, through well and design of the drilling process, to the design of reservoir stimulation treatments, including secondary fracturing [13, changed] 
- location and state of stresses, in the vicinity of noncontinuous tectonic elements,

- pore pressure,

- tectonic stress, overburden stress and their impact on the in situ stresses distribution,

- reservoir and overburden architecture in 3 dimensions.

If we take into account the changes over time, of elements mentioned above, we will be dealing with a dynamic Mechanical Earth Model or 4D MEM [16].

For a reliable MEM construction an integration of geological, geophysical, engineering data, previously constructed static models and the results of reservoir simulations is necessary, as it is presented in Fig. 1.

\section{The role of geomechanics in the reservoir stimulation design procedure}

The success of the intensification treatment through hydraulic fracturing in the reservoir rock, is dictated by the susceptibility of geological formation, to produce a complex network of artificial fractures. Thus, for the proper design of the treatment, the recognition of the factors affecting the brittleness of the rock subjected to the fracturing is crucial. Whether the rock mass subjected to the pumped, under high pressure fracturing, mixture, behaves in a brittle or a plastic manner, depends on its elastic properties, such as Young's modulus (E) (2) or Poisson's ratio (v) (3) [1, 2, 4, $10,13,19]$.

$$
E=\delta / \varepsilon
$$

where:

$E$ - Young modulus [psi; $\mathrm{MPa}$,

$\delta$ - stress [psi; MPa],

$\varepsilon-$ relative linear strain.

$$
v=-\varepsilon_{x} / \varepsilon_{z}
$$

where:

$v$ - Poisson's ratio,

$\varepsilon_{x}$ - relative axial strain,

$\varepsilon_{z}-$ relative transverse strain.

The knowledge of the spatial distribution of these parameters combined with the information about the value (magnitude) and direction of the acting stresses, allows for hydraulic fracturing design, including the geometry of created fractures and the pressure, under which the fracturing fluid should be injected to the target formation.

\section{Hydraulic fracturing}

Currently, the common technological process employed to enable economical gas production from the unconventional formations, is hydraulic fracturing. The aim of the treatment is to improve (enlarge) the contact zone between the reservoir rock and wellbore, allowing previously trapped gas, to flow freely into the well. This improved reservoir exposition to the wellbore happens through the creation of complex artificial fractures network, which become a path for the reservoir fluid into the well, in economically viable quantities [15].

Hydraulic fracturing is the process of injecting the fracturing mixture (usually $90 \%$ of water, $9.5 \%$ of sand and chemical additives, to facilitate the transportation of proppant including gelling and anti-corrosion agents and bactericides) at a high pressure to the geological formation [22]. When the pressure of pumped fluid exceeds rock fracturing pressure - the pressure at which the rock breaks, a creation of new fractures or the reopening of preexisting, sometimes healed with minerals, can be observed [8]. The aperture of the generated in this way fractures, reaches a few mms and their length can reach several tens or even hundreds of meters in the horizontal direction and up to tens of meters in vertical direction. The ingredient with propping properties, sustains the effect of the opened fracture, due to the fracture-closure pressure $\left(\sigma_{h}\right)$ [22].
Particularly, due to the poor quality of unconventional reservoir parameters, mainly low or almost zero permeability (from 0.000001 to $0.0001 \mathrm{mD}$ in shale formations and from 0.0001 to $0.5 \mathrm{mD}$ in tight sandstones), an intensification of treatments for such a formation are required, to enable the economic production of natural gas from these formations $[5,15]$.

\section{Secondary fracturing}

Secondary fracturing is one of the re-stimulation treatments, which aims to increase hydrocarbons recovery. It is carried out in formations previously being produced from. Sometimes secondary fracturing may affect a different perspective area, or can be performed in the interval, for which the effects of previous treatment were unsatisfactory, due to the low degree of fracturing within the interval or poor communication between created fractures. Mostly, however, this procedure is performed in order to increase production, by creating additional exposure of the reservoir rock to the wellbore zone, without bearing the expenses for drilling a new well.

\section{The phenomena of fractures reorientation}

Originally, re-fracturing was a corrective treatment performed in wells with low hydrocarbons production, with 
low ranged fractures or ones revealing a low degree of connectivity. There are numerous cases, where the re-stimulation of previously fractured reservoirs resulted in a significant increase in the production of hydrocarbons.

Production tests and calibration of reservoir stimulation model, taking into account both the presence of the created orthogonal fractures and anisotropic distribution of permeability in the horizontal direction, in many examined boreholes indicate a high probability of direction change of secondarily formed fractures [23].

In Fig. 2 a sketch of the transverse section of the vertical section of the borehole shows a primarily created fracture oriented along the $x$ axis $\left(\sigma_{H}\right)$, as a result of primary hydraulic fracturing, and reoriented along the $y$ axis $\left(\sigma_{h}\right)$ part of the fracture, as a result of secondary fracturing. Production of hydrocarbons initiated after the formation of the primary fracture in the $x$ direction, can lead to local changes in the distribution of pore pressure, within an ellipsoidal area (marked with dark blue dashed line) around the borehole and primary fracture (Fig. 2).

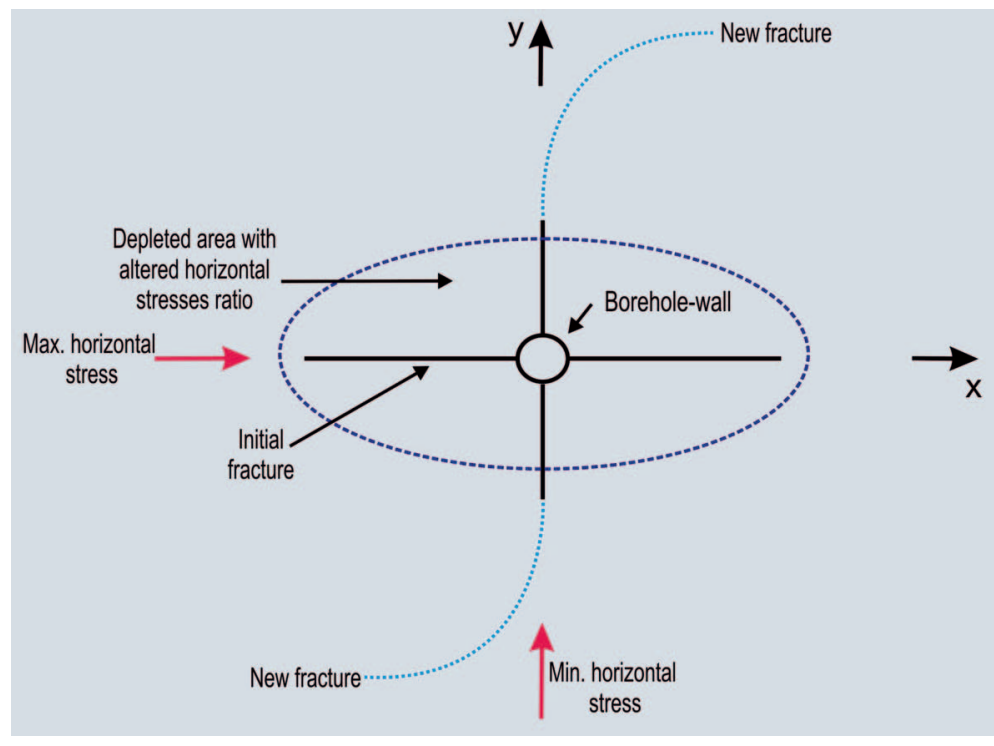

Fig. 2. Change of the orientation of the stresses in the rock mass and observed orthogonal propagation of the fracture

The border of the region with altered stresses distribution, is determined by the isotropic points with the initial magnitude of horizontal stresses. Reorientation of the principal axis of stresses in the reservoir and propagation of the fracture, in a different, from the original direction, demonstrates the response of the pore pressure change in secondary fracturing and unexpected increase of production rate from the wells, subjected to the secondary treatment, which is an effective result after primary fracturing.

The idea of the re-orientation of the fractures resulting from the secondary intensification treatment, is not a new issue and has been the subject of modeling in many experimental studies [18].

Numerous tests carried out under laboratory conditions have shown, that changes in pore pressure acting on the rock matrix, affect the propagation and therefore direction of the fractures [18]. In general, the hydraulically induced fractures propagate along the direction of maximum horizontal stress $\left(\sigma_{H}\right)$ or perpendicular to the higher stress gradient. Additionally, the phenomena of fractures reorientation depends on the existence of anisotropy in the analyzed object. For instance, in the media where the differences of horizontal stresses magnitude in two mutually perpendicular directions are balanced with naturally occurred anisotropy, the fractures reorientation cannot take place. The change of pore pressure in the vicinity of the fracture network penetrating the reservoir, results in high stress gradient, which may be the direct cause of the reorientation of the secondarily created fractures. When the changes in stresses distribution reach a critical point, the gradient decreases gradually with the progressive depletion of hydrocarbons. An example of fracture reorientation was provided in the study by Dozier [7], where the simulations suggested the possibility of a change in direction of fracture propagation by $90^{\circ}$ with respect to the original azimuth of the primarily created fracture.

The value (magnitude) of the horizontal stress, parallel to the direction of the primarily generated fracture, decreases faster than the magnitude of the horizontal stress, perpendicular to the fracture. As a result of changes in the magnitude of stresses, exceeding the initial magnitude of the differential stress, the fracture propagation occurs on the plane of the azimuth, different from the azimuth of the primarily generated fracture until the fracture leaves the elliptical area with the altered stress distribution (Fig. 2).

The fractures can further propagate for some distance, their length depends on the mechanical properties of the formation, on the plane with the changed azimuth direction.

There are many factors contributing to the size of the area with altered stresses distribution. Among them are: history of the hydrocarbons exploitation, reservoir pay thickness, elastic properties of the pay thickness and the formations in close vicinity, the size and geometry of generated fractures, permeability of the reservoir formation, and also the difference in magnitude between two horizontal stresses before and during the hydrocarbons exploitation. These factors can be subjected to modeling and should be taken into account at the stage of selecting the wells, which are to be subjected to re-fracturing. Computer simulations allow to determine the optimal point during primary hydrocarbons 
production, at which a re-stimulation would attain the most efficient results.

As already mentioned, change in fractures orientation have been already observed after secondary fracturing. An example of a formation subjected to the successful treatment is Barnett Shale formation, North Fort Worth field (Texas, USA). The effects of the treatment were monitored with a group of tiltmeters installed both, at the surface and along the well trajectory.

\section{Geomechanical modeling}

The subject of this study is the phenomenon known from the literature as "stress shadowing", which refers to the occurrence of altered $\mathrm{min} / \mathrm{max}$ horizontal stress ratio, located in the area being under hydrocarbons exploitation. This phenomenon may lead to changes in the direction of fracture propagation up to 90 degrees, generated after the period of production, as a result of pore pressure decrease in the hydrocarbons depletion area.

In the presented case the geomechanical modeling was performed with the use of a combination of three Schlumberger software platforms accessible from Petrel 2013.2, where:

- static model of the reservoir was constructed in Petrel,

- pore pressure profiles during the 20 year history of hydrocarbons production were simulated in the Eclipse reservoir simulator hidden beneath a Reservoir Engineering module in Petrel, and finally,

- geomechanical modeling was performed with the use of the Visage geomechanical simulator, hidden beneath a Reservoir Geomechanics plugin inside Petrel 2013.2.

The work within the single Petrel platform allowed for time-saving use of the same data set, at various level of the workflow.

\section{Geological characterization of the analyzed object. Data presentation}

In this study the authors considered a synthetic sandstone reservoir object $610.00 \mathrm{~m}$ wide and $15.25 \mathrm{~m}$ thick. Shale layers, revealing near to zero permeability $(0.0001 \mathrm{mD})$ of $76.20 \mathrm{~m}$ thickness each are laying below (light purple) and above (light green) the sandstone reservoir (Fig. 3).

In the central part of the reservoir, located in the normal stress regime (among three principal stresses, lithostatic stress is the one of largest magnitude), a vertical fracture oriented in N-S direction and assumed permeability of $1000 \mathrm{mD}$ can be observed (Fig. 4). For the comparison, the permeability of the reservoir is $0.1 \mathrm{mD}$. The orientation of the fracture is consistent with the direction of the maximum horizontal stress. As can be seen, in the vicinity of the fracture a gradual grid refinement method was applied in order to increase the grid density and therefore increase the resolution in the area of hydrocarbons production.

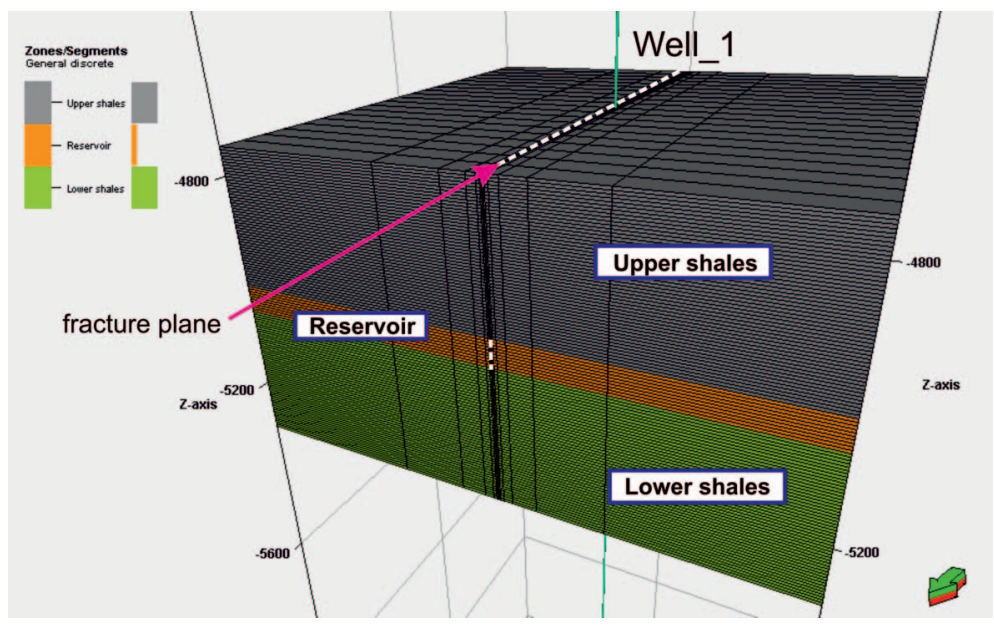

Fig. 3. The geometry of the modeled reservoir object consisting of a sandstone layer (dark green) and a layer of shales above (light green) and below (light purple) the reservoir. In the center of the object, a vertical oriented in the N-S direction fracture is located (marked with the pink dashed line). In the vicinity of the fracture, a gradual grid refinement method was applied, in order to increase the grid resolution in the area of hydrocarbons production

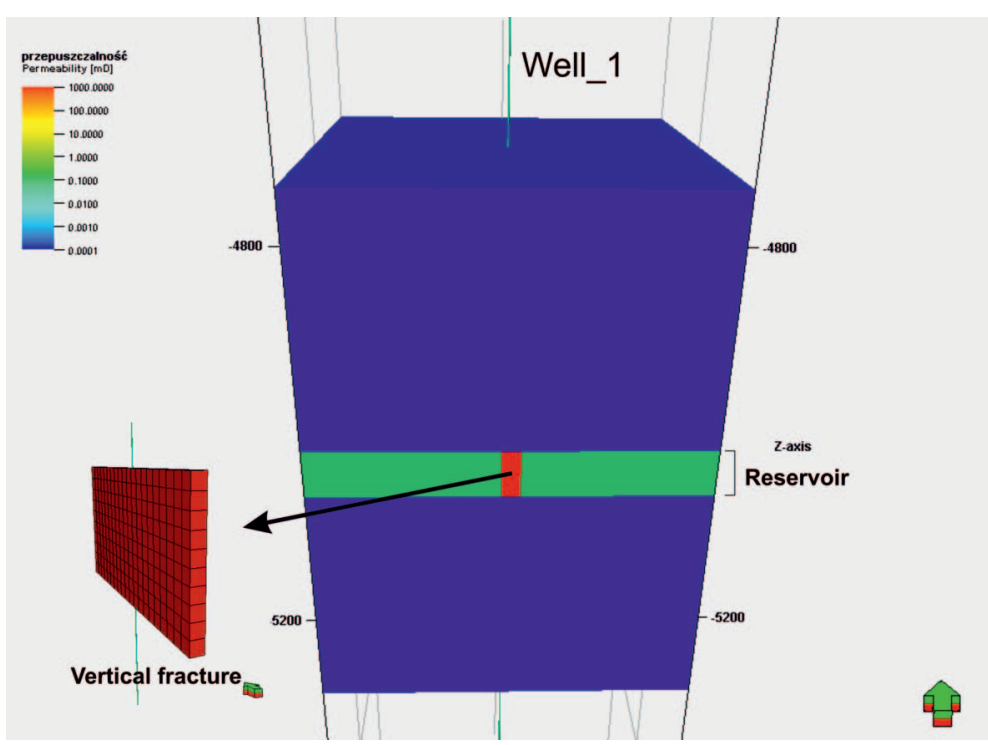

Fig. 4. The geometry of the object with the presented distribution of permeability. Shale layers with near to zero permeability $(0.0001 \mathrm{mD})$ are over- and underlying the sandstone reservoir with permeability of $0.1 \mathrm{mD}$. In the central part of the reservoir, a vertical fracture (zoomed in on the right side) is located with the permeability of $1000 \mathrm{mD}$ 
In the central part of this theoretical object a vertical well, called Well-1, was drilled through the reservoir and underlaying layer of shales. Based on the available well logs, a distribution of the following parameters necessary for furher simulation were calculated: permeability (PERM), total porosity (PHIT), effective porosity (PHIE), pore pressure (PPRS), Gamma Ray (GR), water saturation (SW). The abbreviations are consistent with the API (American Petroleum Institute). The parameters mentioned above are listed in Table 1.

\section{Reservoir simulation}

Having a necessary grid of the reservoir object constructed and the reservoir properties with relevant resolution modeled, the reservoir simulation was performed in the Reservoir Engineering module, in Petrel. In the initial stage of the simulation, reservoir fluid properties (PVT properties) were defined, as well as the relative permeability curves. The assumed value of the initial bed temperature was equal to $77^{\circ} \mathrm{C}$, and the weight of natural gas was equal $0.69 \mathrm{~g} / \mathrm{cm}^{3}$. A reservoir pressure limit equal to atmospheric, and estimated gas flow rate of $28316850 \mathrm{~m}^{3} /$ day was determined. Reservoir simulation resulted in reservoir pore pressure profiles changing, with the ongoing 20 year production of hydrocarbons which are presented in Fig. 5 and Fig. 6. Later these changes, had an influence on the local change of stress state, especially in the near vicinity of the producing vertical fracture.
Table 1. The set of parameters calculated from synthetic well logs, necessary in further simulation workflow

\begin{tabular}{|l|c|c|c|}
\hline $\begin{array}{l}\text { Parameter } \\
\text { [unit] (range of value) }\end{array}$ & $\begin{array}{c}\text { Shale } \\
\text { (upper } \\
\text { boundary) }\end{array}$ & $\begin{array}{c}\text { Sandstone } \\
\text { (reservoir) }\end{array}$ & $\begin{array}{c}\text { Shale } \\
\text { (lower } \\
\text { boundary) }\end{array}$ \\
\hline Gamma Ray (GR) [API] & 250 & 25 & 250 \\
\hline Effective porosity (PHIE) (0-1.0) & 0.05 & 0.15 & 0.05 \\
\hline Total porosity (PHIT) (0-1.0) & 0.06 & 0.15 & 0.06 \\
\hline Gas saturation (SG) (0-1.0) & 0 & 0.75 & 0 \\
\hline Water saturation (SW) (0-1.0) & 1 & 0.25 & 1 \\
\hline Permeability (PERM) [mD] & 0.0001 & 0.0001 & 0.0001 \\
\hline Poisson's ratio (PR) (0-1.0) & 0.33 & 0.15 & 0.33 \\
\hline Caliper (CALI) [mm] & 216 & 216 & 216 \\
\hline Young modulus (YME) (GPa) & 41.3685 & 20.6843 & 41.3685 \\
\hline Alpha index (ALPH) & 3.28 & 3.28 & 3.28 \\
\hline
\end{tabular}

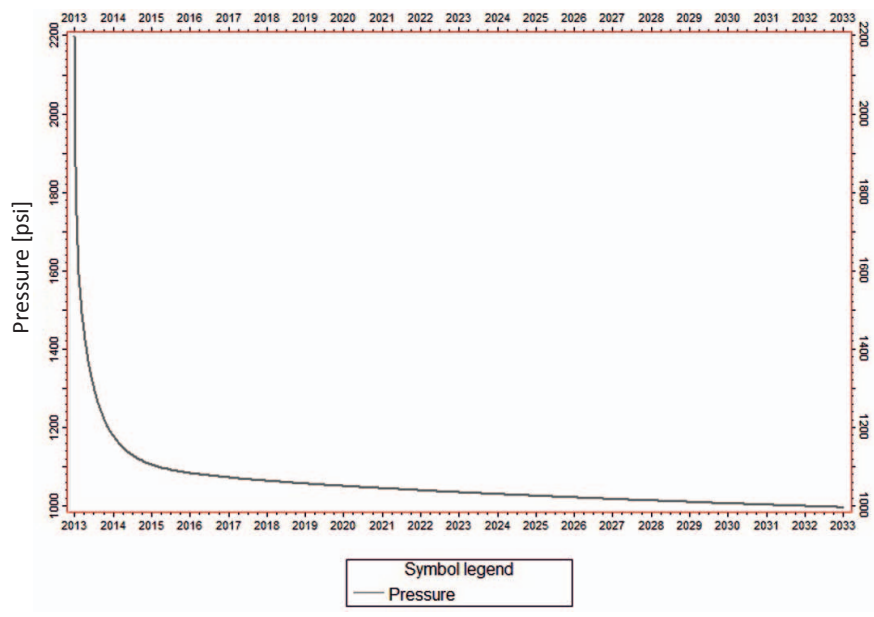

Fig. 5. The results of the reservoir simulation: pore pressure decrease during 20 years of exploitation, from 2013 to 2033

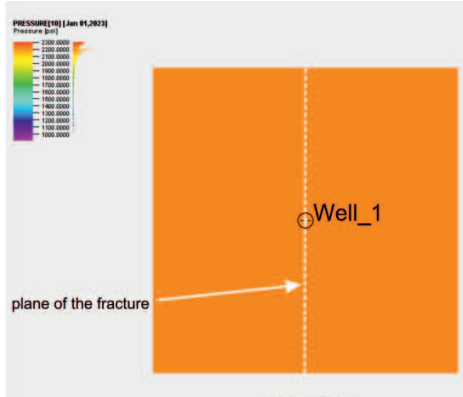

2013

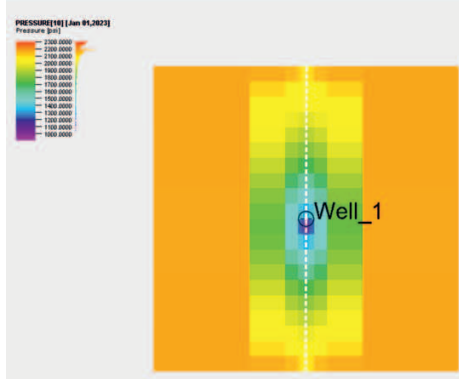

2023

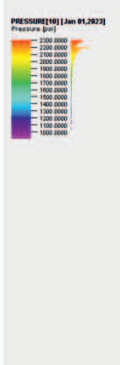

1

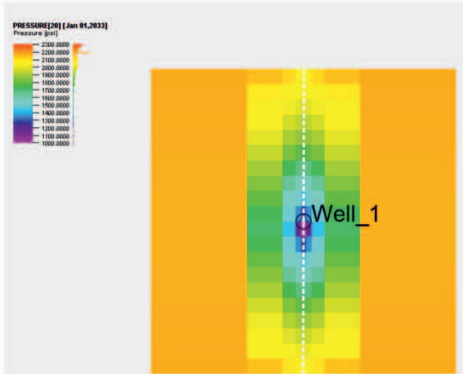

2033

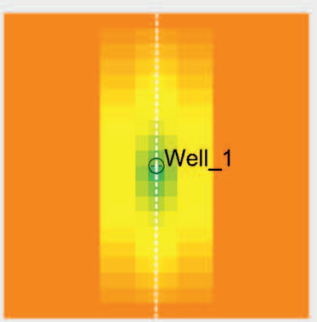

2014

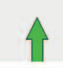
after 10 years of exploitation (2023) and after 20 years of exploitation (2033). The hydrocarbons production takes place through the fracture surface, oriented in a N-S direction, located in the central part of the reservoir 


\section{Modeling of mechanical properties}

Mechanical modeling was carried out in the Reservoir Geomechanics plugin, in the Petrel software platform.

In order to reconstruct the underground conditions reflecting the pressure with which the neighboring rocks are acting on the reservoir, prior to geomechanical simulation, reservoir embedding was applied. In this process the object was embedded with additional grid cells, so the total object length reached $2438.4 \mathrm{~m}$ in the horizontal plane (sideburden) and total thickness of $1828.8 \mathrm{~m}$ in the vertical direction. The overburden started at 0 relative depth and underburden reached a depth of $-1828.8 \mathrm{~m}$ (Fig. 7).

After reservoir embedding the mechanical parameters of rock masses were determined (Tab. 2, 3, 4).

The resulting pore pressure profiles from the reservoir simulation, were used in the geomechanical modeling, to obtain gradual change of distribution of stresses caused by the ongoing 20 year gas production. Detailed description of the projection of the analyzed object

Table 2. Elastic parameters of the model fulfilling assumed elastic criteria for the reservoir (sandstones) and upper and lower boundary (shales)

\begin{tabular}{|c|c|c|c|}
\hline $\begin{array}{l}\text { Parameter } \\
\text { [unit] (range of value) }\end{array}$ & $\begin{array}{l}\text { Shale (upper } \\
\text { boundary) }\end{array}$ & $\begin{array}{l}\text { Sandstone } \\
\text { (reservoir) }\end{array}$ & $\begin{array}{l}\text { Shale (lower } \\
\text { boundary) }\end{array}$ \\
\hline Young modulus [GPa] & 36 & 15 & 36 \\
\hline Poisson's ratio $(0-1)$ & 0.2 & 0.25 & 0.2 \\
\hline Bulk density $\left[\mathrm{g} / \mathrm{cm}^{3}\right]$ & 2.52 & 2.65 & 2.52 \\
\hline Biot constant & 1 & 1 & 1 \\
\hline $\begin{array}{l}\text { Thermal volume expansibility index } \\
\text { (Rankine scale) }[1 / \mathrm{degR}]\end{array}$ & $7.222222 \cdot 10^{-6}$ & $7.222222 \cdot 10^{-6}$ & $7.222222 \cdot 10^{-6}$ \\
\hline Uniaxial compressive strength [MPa] & 125 & 125 & 125 \\
\hline Friction angle $\left[^{\circ}\right]$ & 14.1 & 34.9 & 14.1 \\
\hline Angle of dilatation $\left[{ }^{\circ}\right]$ & 7.2 & 17.45 & 7.2 \\
\hline Tensile strength $[\mathrm{MPa}]$ & 6 & 7.5 & 6 \\
\hline
\end{tabular}

Table 3. Assumed geomechanical parameters of the overburden of the basic model

\begin{tabular}{|l|c|}
\hline Lithostatic stress gradient $\sigma_{v}$ & $0,0226 \mathrm{MPa} / \mathrm{m}$ \\
\hline Pore pressure gradient $P_{p}$ & $0,0099 \mathrm{MPa} / \mathrm{m}$ \\
\hline Additional pore pressure & $0,0 \mathrm{MPa}$ \\
\hline
\end{tabular}

Table 4. Parameters describing initial stress conditions acting within three model variants with initial $\sigma_{H} / \sigma_{h}$ ratio:

$1.01 ; 1.07 ; 1.15$

\begin{tabular}{|l|c|}
\hline Gradient $\sigma_{h}$ & $0.01493[\mathrm{MPa} / \mathrm{m}]$ \\
\hline Azimuth $\sigma_{H}\left[^{\circ}\right]$ & 90.00 \\
\hline
\end{tabular}

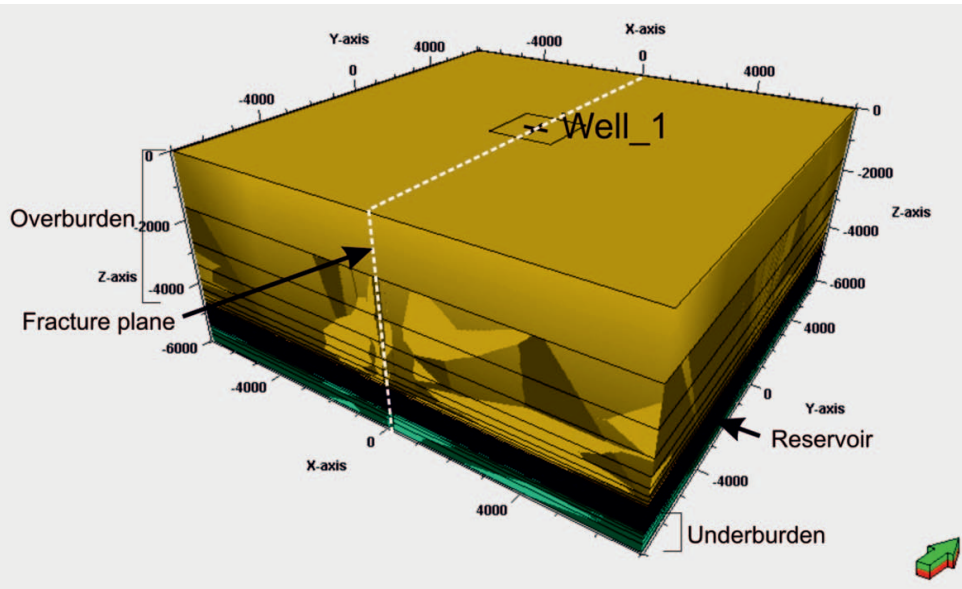

Fig. 7. The reservoir object; the initial size marked with the black line on the top surface, embedded with over-, under-, and side burden, in order to reconstruct the underground conditions and pressure of the neighboring rocks, acting on the reservoir. The white dashed line indicates the oriented, in the N-S direction, vertical fracture, whose projection onto the top of the overburden is marked with a blue dotted line

onto a horizontal plane, perpendicular to the vertical axis, consistent with the trajectory of the vertical well, called Well-1 is presented on Fig. 8.

In the central part of the object, a vertical fracture oriented in the $\mathrm{N}-\mathrm{S}$ direction (which is consistent with the direction of $\sigma_{H}$ ) is marked with a red dashed line. The vicinity of the producing fracture, in the shape of an ellipsoidal area, is marked with a blue dashed line. This area is expected to be particularly subjected to stress changes, due to hydrocarbons depletion. The area neighboring with the reservoir sideburden is marked with red dotted line. The apparent lack of symmetry on the image results from the projection angle. The vectors being the result of simulation (in this particular case - initially close to isotropic state of the reservoir is marked with the yellow tone color) indicate the real state of horizontal stresses (pressures) calculated from the data, showing both, the direction of stresses and its magnitude, according to the color bar (called tensor in the further description after Petrel manual).

The model assumed for simulation purposes is corresponding to the normal stress regime. In such state of stresses, which is the most common tectonic regime occurring in the real geological media, among three principal stresses, the lithostatic stress is dominant and perpendicular to the orientation of the maximum $\left(\sigma_{H}\right)$ and minimum $\left(\sigma_{h}\right)$ horizontal stresses. 


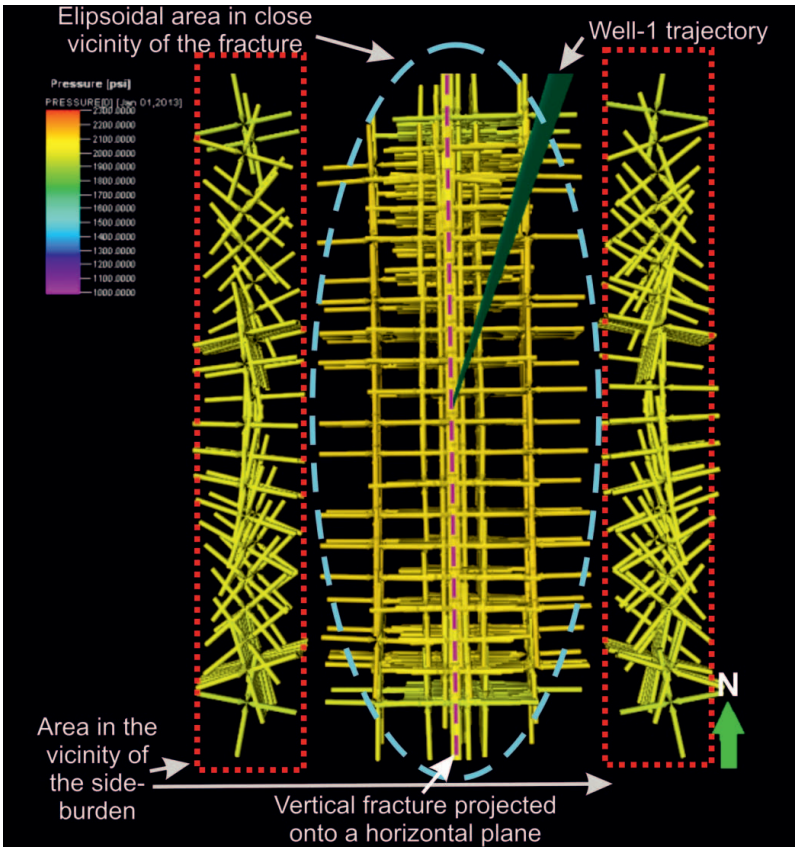

Fig. 8. The zoom of the projection of the analyzed object, onto a horizontal plane, perpendicular to the vertical axis, consistent with the trajectory of the vertical well, called Well-1

What's more, the direction of the existing analyzed object fracture, is consistent with the direction of the maximum horizontal stress.

The three suggested variants of the initial ratio of the horizontal stress $\sigma_{H} / \sigma_{h}$ acting on the reservoir, subjected to geomechanical simulation were the following: 1.01 ; 1.07 and 1.15 . This practically allowed for the analyzed the variant with the ratio closest to isotropic conditions $\sigma_{H} / \sigma_{h}=1.01$. A small degree of change can be observed in case of variant $\sigma_{H} / \sigma_{h}=1.07$. No noticeable changes in case of the variant with the most anisotropic initial conditions $\sigma_{H} / \sigma_{h} 1.15$ was noted. Based on the reservoir pressure simulation and accompanying changes in the state of the stresses, a significant change in stress state was observed after a period of 5-6 years of ongoing hydrocarbons exploitation for the first variant $\left(\sigma_{H} / \sigma_{h}=1.01\right)$. In addition, after the first year of production, observable changes in the horizontal stresses direction of up to 45 degrees were recorded for the ratio $\sigma_{H} / \sigma_{h}=1.01$. This suggests that the treatment of secondary fracturing is most reasonable, when we are dealing with the reservoir initially revealing isotropic horizontal stress state. During further stages of production, the pore pressure decreases at a slower pace, and the state of stresses is gradually stabilizing. The changes in a stress direction accompanying progressive hydrocarbons depletion (decrease in reservoir pressure) in the case of variant $\sigma_{H} / \sigma_{h}=1.01$ are presented in Fig. 9.

As can be observed, vertical stress is dominant in magnitude, while horizontal stresses are close to each other $\left(\sigma_{H} / \sigma_{h}=1.01\right)$. Initially (before the exploitation $\left.-2013 \mathrm{~A}, \mathrm{~B}\right)$, the direction of maximum horizontal stress $\left(\sigma_{H}\right)$ was consistent with the fracture direction (N-S). A change between total (A) and effective stress (B) magnitude is also visible, as the magnitude of effective stress (B) is reduced with reference to total stress (A), by the magnitude of pore pressure. It is
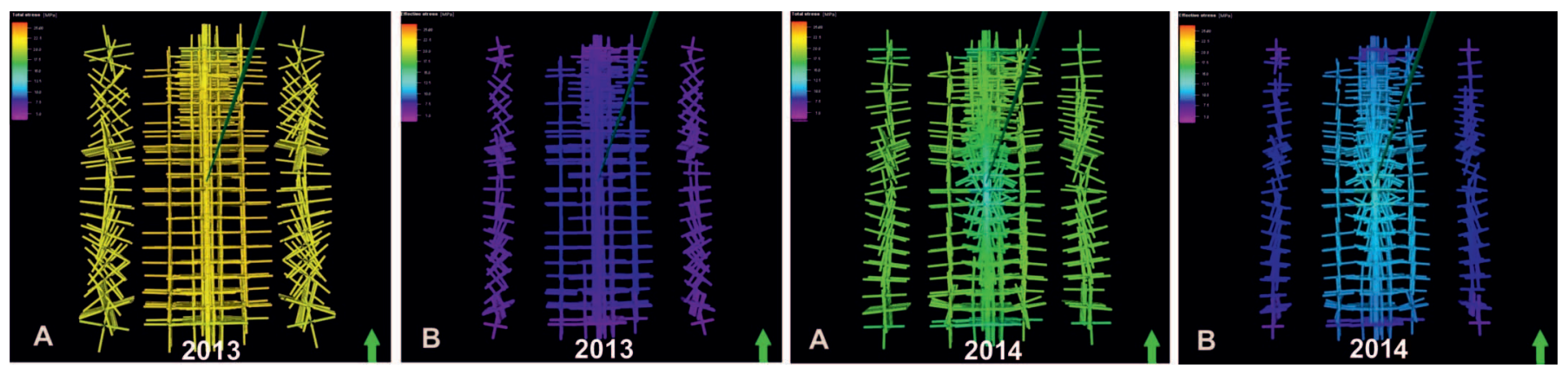

Fig. 9. Distribution of total horizontal stresses (A) and effective horizontal stresses (B) before the hydrocarbons exploitation (2013) and after one year of exploitation (2014) in the analyzed variant of $\sigma_{H} / \sigma_{h}=1.01$

condition from near isotropic to weak anisotropic media. These three variants of initial horizontal stresses rations $\sigma_{H} / \sigma_{h}$, were treated equivalently. It means, they were subjected to simulation with the only change of the stresses ratio, while the distribution of other parameters and simulation settings were unchanged. It was observed, that the degree of the horizontal stresses orientation change, depends on the initial horizontal stress ratio. Among the tested relations $\left(\sigma_{H} / \sigma_{h}=1.01 ; 1.07\right.$ and 1.15$)$, the greatest degree of change in stresses direction was observed for noticed, that in the area in close vicinity of the fracture, after one year of hydrocarbons exploitation, the stresses direction are strongly altered and their magnitude reveal the most significant changes in the borehole area.

On Fig. 10 the changes in distribution of total and effective stresses before and after hydrocarbons production for the variant $\sigma_{H} / \sigma_{h}=1.07$, can be seen.

Vertical stress is dominant in magnitude, and horizontal stresses exhibit relationship $\sigma_{H} / \sigma_{h}=1.07$. Initially (before the exploitation) the direction of maximum horizontal stress $\left(\sigma_{H}\right)$ 

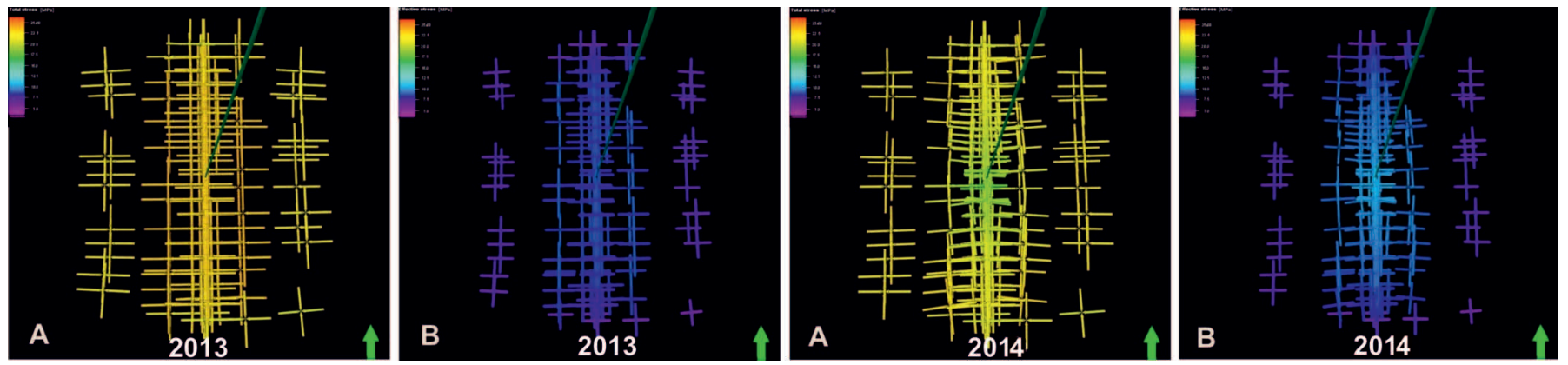

Fig. 10. Distribution of total horizontal stresses (A) and effective horizontal stresses (B) before hydrocarbons exploitation (2013) and after one year of exploitation (2014) in the analyzed variant of $\sigma_{H} / \sigma_{h}=1.07$
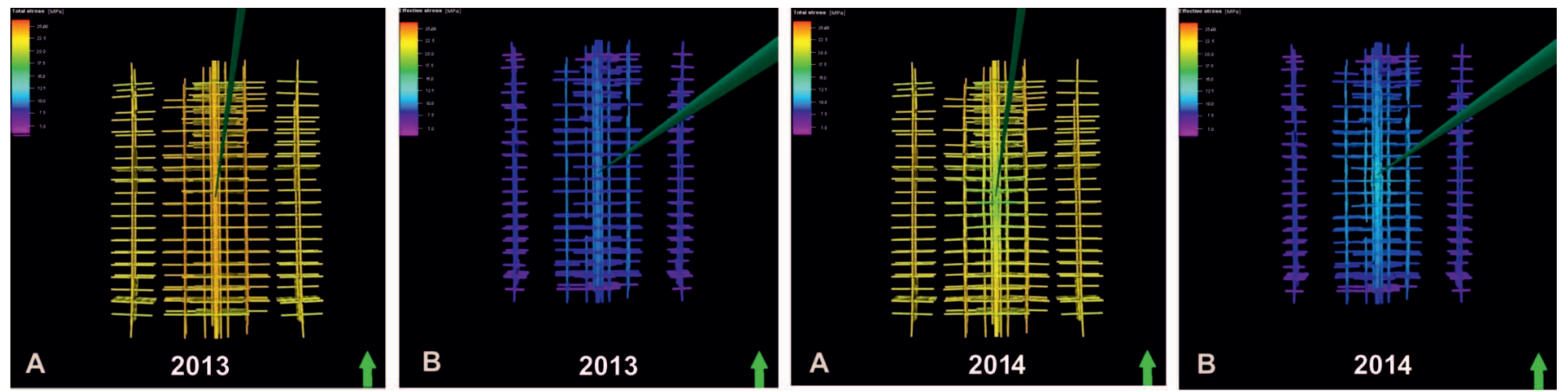

Fig. 11. Distribution of total horizontal stresses (A) and effective horizontal stresses (B) before the hydrocarbons exploitation (2013) and after one year of exploitation (2014) in the analyzed variant of $\sigma_{H} / \sigma_{h}=1.15$

was consistent with the fracture direction (N-S). A visible change between total and effective stress magnitude can be observed, as the magnitude of effective stress is reduced with reference to total stress, by the pore pressure, dropping with ongoing production. After one year of hydrocarbons production, a very slight rotation of the horizontal stresses can be noticed.

In turn, changes in the distribution of the total and effective horizontal stress, before and during ongoing production, for the variant $\sigma_{H} / \sigma_{h}=1.15$ were presented on Fig. 11.

The dominant in magnitude is vertical stress and horizontal stresses exhibit relationship $\sigma_{H} / \sigma_{h}=1.15$. Initially (before the exploitation) the direction of maximum horizontal stress $\left(\sigma_{H}\right)$ was consistent with the fracture direction $(\mathrm{N}-\mathrm{S})$. A visible change between total and effective stress magnitude can be observed, as the magnitude of effective stress is reduced with reference to total stress, by the pore pressure decreasing with ongoing production. After one year of hydrocarbons production, no rotation of the horizontal stresses was noticed.

The initial position of the stress tensor at the borders of the reservoir in all of the presented cases is interpreted firstly, as result of ongoing exploitation, and secondly, because of the effect of transition in the grid geometry (grid cell size) in the contact zone between the reservoir and the sideburden area of the object.

The results of the three subjected to the analysis, examples $\left(\sigma_{H} / \sigma_{h}=1.01 ; 1.07\right.$ and 1.15$)$ confirms the theoretically expected behavior.

\section{Conclusions}

1. The concept and procedures within Mechanical Earth Model allow for visualizing the state of stresses and tracking the changes based on geological, geophysical and reservoir engineering data.

2. Decrease of the pore pressure due to ongoing production of hydrocarbons is the direct cause of change in the state of stresses.

3. The above phenomena cause a gradual decrease of total horizontal stress during the production of hydrocarbons.

4. Among examined relationships between horizontal stresses
$\left(\sigma_{H} / \sigma_{h}=1.01 ; 1.07\right.$ and 1.15$)$ subjected to simulation, it is concluded that for the assumed parameters of geological masses, secondary fracturing treatment will bring the best results, when the ratio of the horizontal stresses is close to isotropic (i.e. $\sigma_{H} / \sigma_{h}=1.01$ ).

5. This means, that the best results refer to the refracturing of the initial isotropic medium. However, the possibility of the return to the original isotropic state of horizontal stresses of the reservoir, which acquired anisotropic character during hydrocarbons exploitation, cannot be excluded. 
6. In the case of the relation between two horizontal stresses $\sigma_{H} / \sigma_{h}=1.01$, the direction of the axis parallel to the $\sigma_{H}$ rotates by about 45 degrees.

7. Analysis of the visualized horizontal stresses in the fracture vicinity and the surrounding area, allow to specify time accuracy and treatment parameters of the secondary fracturing. In the case of the examined model, a critical period for the refracturing appears to be 10 years of hydrocarbons production, under assumed initial horizontal stresses relationship $\sigma_{H} / \sigma_{h}=1.01$.

\section{Summary}

Hydraulic fracturing treatment preceded with reliable geomechanical analysis of the reservoir, whether carried out immediately after well completion or during later stages of the reservoir lifetime (refracturing among others), helps to avoid near-wellbore area damage and the hydrocarbons production increase. This is realized through the creation of the artificial fracture network, and therefore, enabling free flow of the gas from the unconventional formation into the wellbore. The practice of stimulation treatment by fracturing the geological formation goes way back to 1947, but early application of hydraulic fracturing was not successful, due to problems with diagnosis of the complications and selection of wells, that were about to be subjected to the treatment. Over the last two decades numerous cases of successful secondary fracturing were recorded in hydrocarbons reservoirs in North America, Russia, China, Brazil and Algeria. Obviously, hydrocarbon deposits around the world, have the potential for production increase, particularly those in the advanced stages of exploitation. In most of the cases, the use of such treatments is much more economical than determining optimal location, well design, drilling and completion of new well.

Acknowledgments: Schlumberger company for providing necessary software.

\section{Please cite as: Nafta-Gaz 2017, no. pp. 3-13, DOI: 10.18668/NG.2017.01.01}

Article contributed to the Editor 18.07.2016. Approved for publication 9.11.2016.

The article is the result of research conducted in connection with the project: Methodology of determining sweet spots on the basis of geochemical, petrophysical, and geomechanical properties, based on the correlation of the results of laboratory examinations with the geophysical measurements and the 3D generation model, co-funded by the National Centre for Research and Development as part of the programme BLUE GAS - POLISH SHALE GAS. Contract No. BG1/MWSSSG/13.

\section{Literature}

[1] Akbar Ali, Brown A.H, Delgado T., Lee R., Plumb D., Smirnov D., Marsden N., Prado-Velarde R., Ramsey E., Spooner L., Stone D., Stouffer T.: Watching Rocks Change-Mechanical Earth Modeling. Oilfield Review 2008, vol. 9, pp. 22-39.

[2] Barton N.: Rock quality, seismic velocity, attenuation and anisotropy. Taylor \& Francis Group, London 2007, 109 pp.

[3] Bellotti P., Giacca D.: Seismic data can detect overpressures. Oil and Gas Journal 1978, vol. 4, pp. 148-158.

[4] Bjørlykke K.: Petroleum Geoscience: From sedimentary Environments to Rock Physics. Springer 2010, 288 p.

[5] Castillo D.A., Moss D.: Reservoir geomechanics applied to drilling and completion programs in challenging formations: North West shelf, Timor Sea, North Sea and Colombia. Australian Petroleum Production and Exploration Association Journal 2000, vol. 16, pp. 509-520.

[6] Ciechanowska M., Matyasik I., Such P.: Uwarunkowania rozwoju wydobycia gazu z polskich formacji łupkowych. Nafta-Gaz 2013, no. 12, pp. 963-975.

[7] Dozier G., Elbel J., Fielder E., Hoover R., Lemp S., Reeves S., Siebrits E., Wisler D., Wolhart S.: Refracturing works. Oilfield Review 2003, vol. 15, pp. 38-53.

[8] Dunphy R., Campagna D.: Fractures, Elastic Moduli \& Stress: Geological Controls on Hydraulic Fracture Geometry in the Horn River Basin. Conference Paper at Energy, Environment,
Economy Recovery SCPG/CSEG/CWLS convention in Calgary 2011, pp. 1-9.

[9] Fertl W.H.: Abnormal Formation Pressures. Developments in Petroleum Science, Elsevier 1976, 382 pp.

[10] Fjaer E., Holt R.M., Horsrud P., Raaen A.M., Risnes R.: Petroleum Related Rock Mechanics. 2nd Edition. Elsevier 2008, $20 \mathrm{pp}$.

[11] Herwanger J., Koutsabeloulis N.: Seismic Geomechanics: How to Build and Calibrate Geomechanical Models using $3 D$ and 4D Seismic Data. EAGE Publications 2011, 17 pp.

[12] Jędrzejowska-Tyczkowska H., Malaga M., Żukowska K.: Dynamic seismic velocity modeling. First Break EAGE Publications 2011, vol. 29, pp. 73-76.

[13] Jędrzejowska-Tyczkowska, H., Słota-Valim M.: Mechaniczny Model Ziemi - jako nowy i konieczny warunek sukcesu w poszukiwaniach $i$ eksploatacji złóż niekonwencjonalnych. Nafta-Gaz 2012, no. 6, pp. 329-340.

[14] Kasza P.: Efektywne szczelinowanie łupków w Polsce. NaftaGaz 2013, no. 11, pp. 807-813.

[15] King G.E.: Hydraulic Fracturing 101: What every representative, environmentalist, regulator, reporter, investor, university researcher, neighbor and engineer should know about estimating frac risk and improving frac performance in Unconventional gas and oil wells. SPE Hydraulic Fracturing Tech- 
nology Conference held in The Woodlands, Texas 6-8 February 2012.

[16] Plumb R., Edwards S., Pidcock G., Lee D., Stacey B.: The Mechanical Earth Model concept and its application to high-risk well construction projects Schlumberger. IADC/SPE Drilling Conference, New Orleans, Louisiana 23-25 February 2000.

[17] Sayers C.M., Smit T.J.H., van Eden C., Wervelman R., Bachmann B., Fitts T., Bingham J., McLachlan K., Hooyman P., Noeth S., Mandhiri D.: Use of reflection tomography to predict pore pressure in overpressured reservoir sands. SEG Technical Program Expanded Abstracts. 2003.

[18] Siebrits E., Elbel J.L., Hoover R.S., Diyashev I.R., Holditch R.T., Griffin L.G., Demetrius S.L., Wright C.A., Davidson B.M., Steinsberger N.P., Hill, D.G.: Refracture reorientation enhances gas production in Barnett Shale tight gas wheld in Dallas, Texas, 1-4 October 2000.
[19] Slatt R.M.: Important geological properties of unconventional resource shales. Central European Journal of Geosciences 2011, no. 3, pp. 435-448.

[20] Sowiżdżał K., Stadtmüller M., Lis-Śledziona A., Kaczmarczyk W.: 3D geological modeling for prospectiveness evaluation of shale formations. Nafta-Gaz 2015, no. 12, pp. 963-975.

[21] Themig D.: The key to Europe's unconventional success may not be found in the Barnett Shale: Critical Issues for Unconventionals Europe 2013. Conference and Exhibition, Warsaw, 23-24 October 2013.

[22] U.S. Department of Energy, Office of Fossil Energy, National Energy Technology Laboratory: Modern Shale Gas Development in United State: A Primer, April 2009.

[23] Zoback M.D.: Reservoir Geomechanics. Cambridge 2010, $380 \mathrm{p}$.

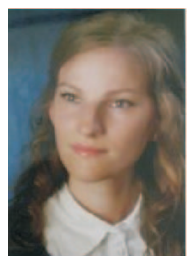

Małgorzata SŁOTA-VALIM M.Sc. Eng.

Junior Scientist

Department of Geology and Geochemistry Laboratory of Petrophysics

Oil and Gas Institute - National Research Institute

ul. Lubicz 25 A, 31-503 Kraków

E-mail: slota@inig.pl

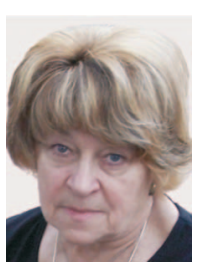

Prof. dr hab. Eng. HALINA JĘDRZEJOWSKATYCZKOWSKA

Assoc. Professor

Oil and Gas Institute - National Research Institute

ul. Lubicz 25 A

31-503 Kraków

E-mail: tyczkowska@inig.pl

VIII MIĘDZYNARODOWA KONFERENCJA NAUKOWO-TECHNICZNA

\section{SRODKI SMAROWE 2017}

KRYNICA ZDRÓJ, 10-12 MAJA 2017 R.

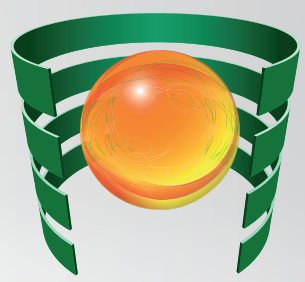

\section{ZAPRASZAMY}

\section{WWW.SRODKISMAROWE2017.INIG.PL}

- producentów środków smarowych, olejów bazowych, dodatków do olejów, smarów i cieczy technologicznych

- dystrybutorów komponentów do środków smarowych

- pracowników działów B+R

- kadre zarządzająca gospodarką smarową

- przedstawicieli uczelni i instytutów badawczych

- $\quad$ producentów i dostawców sprzętu laboratoryjnego

- użytkowników środków smarowych

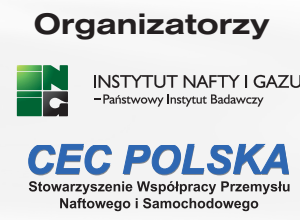

Patroni medialni

Nafta-Gaz

preemysl chemicany

(11) UTRZYMANIE

\section{REJESTRACJA UCZESTNIKÓW}

Joanna Oleksik

Tel. 126177495

e-mail: srodkismarowe@inig.pl 